\title{
Ogólnopolska Interdyscyplinarna Konferencja Naukowa Wiktuaty, kuchnia, kultura jedzenia w przestrzeni historycznej, Kraków, 9-10 IV 2015
}

\section{(1) $\odot$}

http://dx.doi.org/10.12775/KLIO.2015.039

W dniach od 9 do 10 IV 2015 roku w Instytucie Historii Uniwersytetu Pedagogicznego im. Komisji Edukacji Narodowej w Krakowie, odbyła się Ogólnopolska Interdyscyplinarna Konferencja Naukowa Wiktuaty, kuchnia, kultura jedzenia w przestrzeni historycznej. Podobne spotkanie, jednak w nieco mniejszej skali, przygotowało Koło Naukowe Historyków Studentów Uniwersytetu Marii Curie-Skłodowskiej z Lublina w dniach od 19 do 21 X 2011 roku. Pokłosiem tego seminarium jest publikacja pokonferencyjna ${ }^{1}$.

Organizatorem dwudniowej sesji naukowej było Koło Naukowe Doktorantów Historii Uniwersytetu Pedagogicznego. Jest to już czwarte tego typu spotkanie doświadczonych naukowców i młodych badaczy, które zorganizowało Koło Doktorantów. W 2014 roku na rynku wydawniczym ukazała się również recenzowana publikacja zawierająca teksty referatów wygłoszonych podczas Interdyscyplinarnej Konferencji Naukowej, Ciato, seksualność, pornografia - kontekst historyczny.

Celem, jaki przyświecał autorom tegorocznej konferencji, było spojrzenie na jedne z najważniejszych aspektów w życiu jednostki i zbiorowości, czyli jedzenie oraz związane z nim przepisy kulinarne, postrzeganie kuchni w kulturze czy też sprawy gospodarczo-społeczne związane z pożywieniem. Konferencja ta stała się panelem wymiany wyników badań i spostrzeżeń nie tylko historyków, ale także kulturoznawców, etnografów, filozofów, językoznawców czy historyków sztuki. W czasie obrad kładziono nacisk nie na tradycyjne postrzeganie historii o której, jak mawiał prof. Kazimierz

${ }^{1}$ Kuchnia na przestrzeni dziejów. Materiaty konferencyjne, red. Ł. Kosiński, J. Majdanik, T. Pacoch, A. Stelmach, Lublin 2011. 
Wyka, jako o sumie wszystkich polityk ${ }^{2}$, ale na - jakbyśmy mogli powiedzieć - historię „totalną”, związaną z kontekstami: społecznymi, kulturowymi, ekonomicznymi czy też filozoficznymi. Takie podejście do problemu badawczego jakim jest szeroko rozumiane pożywienie, jest blisko związane z francuską szkołą „annalistów”. Dzięki takiej metodzie łatwo zauważamy, że proces dziejowy, związany również z szeroko pojętą kuchnią, to nieustanna ciągłość i zmiana. Warto zwrócić uwagę, że tego typu podejście do historii to wskazanie na nowatorstwo w postawie historyka-badacza, ciaggle bowiem dominuje w naszej historiografii (co oczywiście nie jest ujma) historia polityczna. Projekt ten ponadto wpisał się mocno w nowy nurt badawczy zwany social history oraz $\mathrm{w}$ jeszcze innowacyjną na naszym gruncie badawczym antropologię historyczną.

Sympozjum zgromadziło w Krakowie aż 72 prelegentów z wiodących ośrodków akademickich i badawczych w Polsce, w tym m.in. z Torunia, Gdańska, Warszawy, Wrocławia, Lublina, Katowic, Rzeszowa, Olsztyna i Siedlec oraz jedną referentkę z Czech. Spotkanie zostało podzielone na dziewięć paneli tematycznych, skupionych wokół zagadnień: gospodarki, społeczeństwa, filozofii i literatury, kultury i etnologii, medycyny oraz wojny. Jeden z nich odbywał się poza murami Uczelni w Cechu Rzemiosł Spożywczych w Krakowie.

Obrady konferencji zostały uroczyście otwarte przez prof. Zdzisława Nogę - dziekana Wydziału Humanistycznego, prof. Bożenę Popiołek dyrektora Instytutu Historii, prof. Mariusza Wołosa - opiekuna Koła Naukowego Doktorantów Historii oraz Przemysława Jędrzejewskiego, reprezentującego Koło.

Obrady plenarne rozpoczęły dwa wykłady inauguracyjne: prof. Jarosława Dumanowskiego (Uniwersytet Mikołaja Kopernika w Toruniu) oraz prof. Andrzeja Kuropatnickiego (Uniwersytet Pedagogiczny im. KEN w Krakowie), które wprowadziły zebranych w tematykę wiktuałów, kuchni i kultury jedzenia. Pierwszy panel, dotyczący żywności w gospodarce, otwarły dwa referaty z zakresu archeologii ziem polskich i historii antycznej. Monika Golańska (Uniwersytet Łódzki) omówiła dietę ludności z okresu istnienia kultury ceramiki wstęgowej rytej, a Mateusz Okoński

${ }^{2}$ Por. K. Wyka, Życie na niby. Pamiętnik po klęsce, Kraków-Wrocław 1984, s. 63. 
(UP w Krakowie) przybliżył słuchaczom tematykę gospodarki żywnościowej starożytnych Germanów. Maciej Badowicz (Uniwersytet Gdański) wygłosił referat pt. Pij wino a będziesz dobrze sypiat (...) - importowane wino na krzyżackim stole na przetomie XIV i XV w. Aleksandra Girsztowt (Uniwersytet Gdański) omówiła produkcję pieczywa w Malborku w średniowieczu i okresie wczesnonowożytnym, a Paweł Gąsiorczyk (Uniwersytet Jagielloński) skupił się na problemie diety marynarzy w tym samym czasie. Troje kolejnych prelegentów: dr Arkadia Podgórska (UP w Krakowie), Agnieszka Baran (UP w Krakowie) oraz Grzegorz Ostafin (UJ) przybliżyło słuchaczom zagadnienia związane z produkcją rolno-hodowlaną i dietą klasztorów województwa krakowskiego w XV-XVII wieku Klaudia Skrężyna (UP w Krakowie) wygłosiła referat dotyczący handlu żywnością i płodami rolnymi w małych miastach województwa krakowskiego na przykładzie wielkorządowych Słomnik, z kolei Kamila Woźnica (Uniwersytet Przyrodniczo-Humanistyczny w Siedlcach) omówiła problemy związane z wyżywieniem żołnierza polskiego w XVII wieku. Kolejne dwa referaty przybliżyły słuchaczom kwestię wytwarzania i handlu trunkami. Dr Dorota Dias-Lewandowska (Centrum Badań nad Historią i Kultura Wyżywienia) skupiła się na produkcji wina oraz sprawie jego fałszowania w Polsce w XVII oraz XVIII wieku, natomiast dr Piotr Kitowski (Uniwersytet Gdański) omówił warzenie piwa i wyszynk w kontekście prawnym w małych miastach Prus Królewskich. Piotr Magiera (UP w Krakowie) scharakteryzował gospodarowanie XVIII-wiecznej szlachty litewskiej na przykładzie rodziny Romerów, a Przemysław Jędrzejewski (UP w Krakowie) szczegółowo zaprezentował zmienność cen żywności na targach województwa krakowskiego w drugiej połowie XVIII stulecia. Ostatnim prelegentem tej części konferencji był Kacper Kulpa (UP w Krakowie), który przedstawił problematykę związaną z piwowarstwem na ziemiach polskich w XIX wieku, skupiając się głównie na browarze żywieckim.

Panel zakończono ożywioną dyskusją. Podjęto rozmowę m.in. na temat unikatowości rękopisu Liber perceptarum et expensarum ${ }^{3}$ jako jedynego źródła wiedzy na temat wyżywienia karmelitów z klasztoru „na Piasku” w Krakowie. Porównywano również relację cen mięsa wieprzowego do wo-

3 AKKr., Liber perceptarum et expensarum, rkps 703/295. 
łowego w epoce wczesnonowożytnej z tym samym wskaźnikiem mierzonym współcześnie.

Obrady kolejnej sekcji pierwszego dnia konferencji dotyczyły zagadnienia kuchni w kontekście zróżnicowania społecznego. Ciąg referatów rozpoczęło wystąpienie prof. Bożeny Popiołek (UP w Krakowie) dotyczące kuchni szlacheckiej w okresie saskim. Podobny tematycznie był następny odczyt, Marka Wasilewicza (UJ). Prelegent skupił się na omówieniu typowych potraw serwowanych na dworze Jagiellonów. Dr Marcin Gadocha (UP w Krakowie) i Artur Ziembiński (UP w Krakowie) przedstawili przykłady dań przygotowywanych w szpitalach miast Krakowa i Lwowa, a Anna Penkała (UP w Krakowie) scharakteryzowała rodzaje zastaw stołowych u rodzin szlacheckich, powołując się na inwentarze z krakowskich ksiąg grodzkich z XVIII wieku.

Po krótkiej przerwie kolejnych troje prelegentów zaprezentowało referaty z zakresu nowszej historii. Jako pierwsza wystąpiła dr Aleksandra KmakPamirska (Niemiecki Instytut Historyczny w Warszawie), która omówiła różnicę pomiędzy kuchnią codzienną i świąteczną ziemiaństwa polskiego w XIX wieku. Marzena Koterbicka-Borys (Uniwersytet Rzeszowski) skupiła się na nawykach żywieniowych rodzin chłopskich Galicji w okresie autonomii, natomiast Krzysztof Kloc (UP w Krakowie) omówił problem walki z biedą i głodem w Krakowie w okresie międzywojnia.

Druga część obrad zakończyła się dyskusją prelegentów i publiczności, m.in. o miejscu kultury materialnej oraz roli warsztatu socjologa w badaniach nad tematem kuchni i żywności.

Ostatnia część pierwszego dnia obrad została poświęcona filozoficznym aspektom sztuki kulinarnej. Pierwsze wystąpienie zaprezentowała Beata Fijołek z Uniwersytetu Marii Curie-Skłodowskiej, która na podstawie dzieła sofisty Atenajosa Uczta mędrców $w^{4}$ przedstawiła, jak biesiadowali przy stole starożytni Grecy. Kolejna prelegentka, Natalia Danuta Stala, również z ośrodka w Lublinie, omówiła specyficzną kulturę jedzenia śiwaickich tantryków, związaną z przekraczaniem granic i konwenansów społecznych. Natomiast ostatnia prelegentka, dr Magdalena Harasimowicz z Akademii Ignatianum w Krakowie, podjęła próbę przedstawienia ideologii jedzenia.

${ }^{4}$ Por. Atenajos, Uczta mędrców, Poznań 2010, tłum. K. Bartol, J. Danielewicz. 
Zaakcentowała również, że spośród praktyk zaliczanych do współczesnej kultury jedzenia wiele sięga korzeniami poprzednich epok. Panel zakończyła dyskusja, w której zaakcentowano rolę warsztatu filozofa w badaniach nad historią i kulturą jedzenia.

W drugim dniu obrad prelegenci prezentowali swoje wystąpienia podczas sześciu paneli tematycznych, które odbywały się równocześnie. Sekcja zatytułowana „Motyw wiktuałów w kulturze i sztuce” rozpoczęła się od referatu archeologa Wawrzyńca Miścickiego (UJ), który scharakteryzował znaczenie wina i jego konsumpcji przez pryzmat ikonografii starożytnych Greków. Podjął się również przedstawienia krótkiej analizy sposobu kształtowania się relacji przedmiotu ze zwyczajem w czasie biesiad. Justyna Bąk z Wrocławia, zaprezentowała koncept kulinarny w Rzeczpospolitej doby baroku. Przedstawiła tezę, że to, co można było zaobserwować w architekturze, malarstwie, sztuce XVII wieku miało swoje odzwierciedlenie w sztuce kulinarnej. Ciekawe spojrzenie na ucztę jako temat malarskich przedstawień zaprezentowała Anna Wywioł (UP w Krakowie). Natomiast współczesnej interpretacji jedzenia jako elementu ikonografii tradycyjnego motywu vanitas podjęła się prelegentka z Katowic Agata Stronciwilk. Po przerwie Małgorzata Staszczak-Ciałowicz (UJ) scharakteryzowała elementy savoir vivréu podczas biesiad. Niezwykle interesujące podejście do słynnej kuchni francuskiej we współczesnym przekazie medialnym film, książka, Internet, zaprezentowała Anna Abramowicz-Gajownik z Uniwersytetu Warmińsko-Mazurskiego. Następnie prelegentka z Opola Aleksandra Gałka zarysowała problematykę symboliki i tradycji związanej z jabłkiem i jabłonią. Ostatni referat tego panelu przedstawiła Zofia Żukowska (UP w Krakowie), przybliżając kwestię turystyki kulinarnej jako elementu turystyki kulturowej i historycznej.

Obrady tej części zakończyła dyskusja nad problematyką referatu Anny Abramowicz-Gajownik i wykorzystaniu inspiracji postacią Julii Child w prowadzeniu bloga kulinarnego.

Kolejną część tematyczną konferencji - zatytułowaną „,Kuchnia lecznicza i ziołolecznictwo" - otworzył prof. Franciszek Leśniak (UP w Krakowie), który w swoim wystąpieniu skupił się na XVII- i XVIII-wiecznych specyfikach stosowanych w kuchni leczniczej głównie przez bogatszych ziemian. Podstawą źródłową przedstawionych badań były poradniki i sylwy. Elżbieta 
Nowosielska (Uniwersytet Warszawski, Polska Akademia Nauk) mówiła o tym, jak zdaniem autorów XVII- i XVIII-wiecznych poradników medycznych jedzenie wpływało na kondycję człowieka, które potrawy i składniki uznawano za szkodliwe lub pożyteczne oraz jakie choroby brały swój początek z nieodpowiedniej diety. Kolejny prelegent, dr Wiktor Szymborski (UJ), scharakteryzował leczniczą dietę warszawskich dominikanów w epoce wczesnonowożytnej, powołując się na rachunki klasztoru przechowywane w Archiwum Dominikanów w Krakowie, uzupełnione o wypisy z akt kapituł generalnych zakonu Braci Kaznodziejów autorstwa Kamila Jasińskiego. Barbara Hołub (Uniwersytet Marii Curie-Skłodowskiej) mówiła zaś o alkoholu jako najsilniejszego środku magicznej ochrony i lekarskiego remedium, zaznaczając, że stosowany był jako lekarstwo zwłaszcza wśród ludności wiejskiej w XIX i na początku XX wieku. Karol Ossowski (UJ) omówił cudowne właściwości roślin leczniczych na podstawie informacji z traktatu medyczno-magicznego Kyranides, natomiast ostatnia prelegentka, Beata Golińska (UJ/UP w Krakowie) wygłosiła interesujący referat o intrygującym tytule Culinaria americana, przytaczając liczne przykłady skłonności do kanibalizmu wśród ludów prekolumbijskich.

Część ta zakończyła się dyskusją prelegentów oraz słuchaczy. Jej tematem przewodnim stała się ocena porad medycznych i sposobów leczenia w okresie staropolskim. Wielkie zainteresowanie wzbudził również referat poświęcony kanibalizmowi, o czym świadczyła znaczna liczba pytań i uwag, które pojawiły się w dyskusji.

Szósty panel konferencji został poświęcony wiktuałom w kontekście zróżnicowania etnicznego i kulturowego. Pierwszy prelegent dr hab. Jerzy Ciecielagg (UP w Krakowie) w przejrzysty sposób zaprezentował temat Co Biblia mówi o jedzeniu?. Dwa kolejne referaty Magdaleny KasprzykChevriaux (Uniwersytet Mikołaja Kopernika w Toruniu) i Marcina Zybały (UJ) przybliżyły słuchaczom kuchnię żydowską. Natomiast Magdalena Cebula (Uniwersytet Śląski) zarysowała problematykę kuchni maghrebskiej. Pożywienie górali podhalańskich na przełomie XIX i XX wieku przedstawił Gabriel Szuster (UP w Krakowie). Po krótkiej przerwie Dawid Jędrzejak (Uniwersytet Warmińsko-Mazurski) scharakteryzował Obyczaje romskie związane z jedzeniem i piciem. W niezwykle interesującym wystąpieniu Anna Matras (UJ) podjęła się próby odpowiedzi na pytanie, czym 
jest polska kuchnia narodowa na tle przemian kulturalnych. Temat zbliżony do poruszonego w wystąpieniu Gabriela Szustera omówiła Katarzyna Ceklarz - etnograf z Krakowa, skupiając się na pożywieniu głodowym Podtatrza. Szlaki kulinarne staropolskiej kuchni w Kujawsko-Pomorskiem przedstawiła Agata Wesołowska z Uniwersytetu Kazimierza Wielkiego w Bydgoszczy. Starała się ona wykazać, na ile w omówionych miejscach i inicjatywach możemy odnaleźć rysy dawnej kultury (nie tylko kulinarnej). Ostatni referat tej części konferencji na temat gatunków i połowu ryb w średniowieczu na przykładzie Zalewu Kurońskiego wygłosił Andrzej Gierszewski z Gdańska.

Po tej części rozgorzała ożywiona dyskusja na temat tego, czym jest polska kuchnia narodowa i czy możliwe jest jej precyzyjne zdefiniowanie, skoro w historii ziem polskich nie brakuje wątków wielokulturowych czy wpływów kultury państw ościennych (zwłaszcza z okresu zaborów). Poruszono również problem współczesnych polskich celebrytów kulinarnych, takich jak chociażby Magda Gessler, w porównaniu z kucharzami, np. Karolem Okrasą. Zadano pytanie, którzy z nich promują kuchnię narodową?

W panelu Przepisy i przyrządzanie positków, odbywającym się w zabytkowej sali Cechu Rzemiosł Spożywczych w Krakowie, jako pierwsza głos zabrała Olga Boś z Muzeum Okręgowego w Toruniu, która zaprezentowała swe badania dotyczące statusu pierników w kulturze kulinarnej. Kolejną prelegentką była Magdalena Wiszowata, reprezentująca Instytut Studiów Klasycznych Śródziemnomorskich i Orientalnych Uniwersytetu Warszawskiego, a jej wystąpienie dotyczyło przypraw stosowanych w antyku. Sylwia Skiendziul i Joanna Śliczyńska (Uniwersytet WarmińskoMazurski) omówiły kuchnię wielkich mistrzów krzyżackich. Wystąpienie Sławomira Dorockiego oraz Pawła Brzegowego (UP w Krakowie) przybliżyło uczestnikom konferencji kuchnię lwowskiej inteligencji dwudziestolecia międzywojennego. Grażyna Czernik i Justyna Zyśk (Uniwersytet Warmińsko-Mazurski) zaprezentowały wskazówki żywieniowe XIXwiecznej literatki Lucyny Ćwierczakiewiczowej. Jako ostatnia w panelu dotyczącym przepisów i przygotowywania posiłków wystąpiła Anna Domin (Uniwersytet Papieski Jana Pawła II), która omówiła tematykę kulinarną w prasie kobiecej pierwszej dekady XX wieku. Pytania podczas dyskusji 
odnosiły się do źródeł i badania kuchni krzyżackiej, życiorysu Lucyny Ćwierczakiewiczowej oraz skuteczności leczenia ziołami i stosowania przypraw jako lekarstwa w antyku.

Sesję poświęconą motywowi kuchni w literaturze otworzyła Natalia Giza (UP w Krakowie), wygłaszając angielskojęzyczny referat pt. Ability to cook as an indispensable quality of a Renaissance English „ideal woman” as presented in the conduct literature for women, w którym skupiła się na wzorcu pani domu w czasie panowania Tudorów w Anglii. Marta Sikorska (Uniwersytet Mikołaja Kopernika w Toruniu) omówiła XVII-wieczne rozmówki polsko-niemieckie jaka źródło do historii wyżywienia, natomiast Nadia Konstancja Sola (Uniwersytet Marii Curie-Skłodowskiej) scharakteryzowała polski savoir-vivre na podstawie podręczników Mieczysława Rościszewskiego. Panel zwieńczyło wystąpienie Tomasza Sysika (Uniwersytet Przyrodniczo-Humanistyczny w Siedlcach), który przedstawił jedno z międzywojennych czasopism - „Życie praktyczne” jako przewodnik dla kobiet w gospodarstwie domowym.

Ostatnia część dwudniowego spotkania naukowego dotyczyła kuchni polowej, czyli posiłku w stanie zagrożenia życia. Pierwszy prelegent Paweł Jakubiec (UP w Krakowie) zarysował problemy aprowizacyjne ludności zamieszkującej Galicję w okresie I wojny światowej. W kręgu Wielkiej Wojny pozostał referat Aliny Kucharskiej (Uniwersytet im. Adama Mickiewicza), która również przedstawiła problemy zaopatrzenia w żywność, lecz w odniesieniu do żołnierzy armii niemieckiej. Referent Wiktor Węglewicz (UJ) scharakteryzował problematykę żywieniową jeńców ukraińskich, którzy przebywali w polskich obozach od roku 1918 do 1919. Temat zatytułowany Wyżywienie Polaków deportowanych w kwietniu 1940 r. do Kazachstanu. Zarys zagadnienia zaprezentował prelegent z Uniwersytetu Wrocławskiego Tomasz E. Bielecki. Wystąpienie przygotowano w nurcie oral history. Wygłoszone po przerwie dwa ostatnie referaty: Aleksandry Starzyńskiej z Uniwersytetu Palackiego w Ołomuńcu oraz Katarzyny Odrzywołek i Alicji Śmigielskiej z Centrum Dokumentacji Zsyłek i Wypędzeń dotyczyły kwestii wyżywienia polskich Sybiraków w okresie II wojny światowej.

Podsumowania konferencji w Auli im. prof. Wincentego Danka dokonał prof. Jarosław Dumanowski, który podziękował organizatorom za 
pomysł i trud włożony w organizację konferencji. Podkreślił również wysoki poziom merytoryczny referatów oraz zaakcentował najważniejsze problemy w badaniach nad historią i kulturą jedzenia.

Obrady sesji pozwoliły na integrację środowiska doktorantów oraz przyczyniły się do poszerzenia roli badań interdyscyplinarnych, które stanowią w obecnej nauce nową jakość, pozwalającą na bardziej precyzyjny i pełniejszy obraz poruszanych problemów. Komitet Organizacyjny zapowiedział również, że pokłosiem konferencji będzie obszerna recenzowana monografia, w której autorzy prezentowanych referatów będą mogli poszerzyć przedstawienie swoich badań.

Przemystaw Jędrzejewski

Gabriel Szuster

Klaudia Skrężyna 